\title{
Very low pacemaker rate following ACURATE neo transcatheter heart valve implantation
}

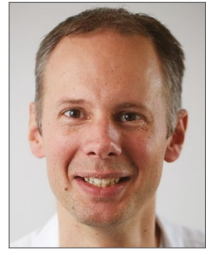

Stefan Toggweiler ${ }^{1 *}, \mathrm{MD}$; Henrik Nissen², MD; Brynjolfur Mogensen ${ }^{3}, \mathrm{MD}$; Florim Cuculi ${ }^{1}$, MD; Christian Fallesen², MD; Karsten Tange Veien², MD; Miriam Brinkert ${ }^{1}$, MD; Richard Kobza ${ }^{1}$, MD; Andreas Rück ${ }^{3}$, MD

1. Heart Center Lucerne, Luzerner Kantonsspital, Lucerne, Switzerland; 2. Odense University Hospital, Odense, Denmark;

3. Karolinska University Hospital, Stockholm, Sweden

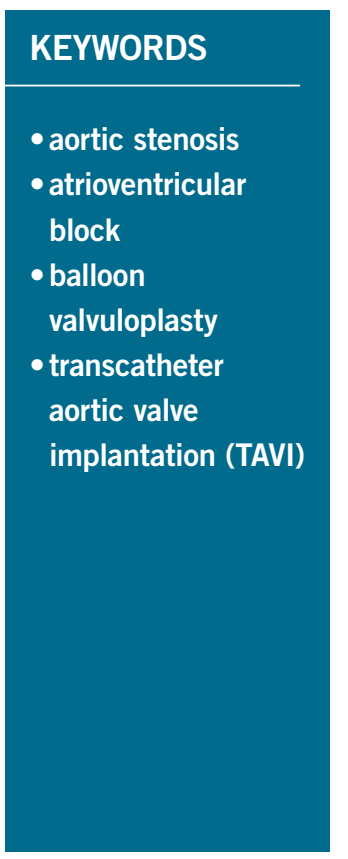

\section{Abstract}

Aims: The aim of this study was to investigate whether minimising trauma to the aortic annulus and left ventricular outflow tract reduces the occurrence of new conduction disorders and the need for permanent pacemakers.

Methods and results: A total of 175 patients ( $58 \%$ female, mean age $83 \pm 6$ years) underwent transfemoral TAVI with the Boston Scientific ACURATE neo at three centres in Europe. Prosthesis size selection was based on perimeter-derived annular diameter. Predilatation was performed in all with a balloon $1.9 \pm 0.9 \mathrm{~mm}$ smaller than the perimeter-derived annular diameter. Post-dilatation was performed in $46(26.3 \%)$ with a balloon $1.2 \pm 0.9 \mathrm{~mm}$ smaller than the perimeter-derived annular diameter. Eighteen patients (10.3\%) developed a new left bundle branch block, 13 (7\%) a new first-degree AV block, and four (2.3\%) received a new permanent pacemaker. Paravalvular regurgitation was none/trace in $66(37.7 \%)$, mild in $101(57.7 \%)$ and moderate in eight (4.6\%). At 30 days, the rate of any stroke was $1.7 \%(3 / 175)$, and one patient $(0.6 \%)$ had died.

Conclusions: With careful selection of the balloon and the ACURATE neo prosthesis size, very low rates of new conduction disorders and permanent pacemaker implantation may be achieved without increasing the amount of paravalvular regurgitation.

\footnotetext{
*Corresponding author: Department of Cardiology, Heart Center Lucerne, Luzerner Kantonsspital, Spitalstrasse 16, 6000 Lucerne, Switzerland.E-mail: stefan.toggweiler@luks.ch
} 


\section{Abbreviations}

$\begin{array}{ll}\text { AVB } & \text { atrioventricular block } \\ \text { BBB } & \text { bundle branch block } \\ \text { LBBB } & \text { left bundle branch block } \\ \text { PAR } & \text { paravalvular regurgitation } \\ \text { RBBB } & \text { right bundle branch block } \\ \text { TAVI } & \text { transcatheter aortic valve implantation } \\ \text { THV } & \text { transcatheter heart valve }\end{array}$

\section{Introduction}

Transcatheter aortic valve implantation (TAVI) has been successfully performed in inoperable, high-risk, and intermediate-risk patients with low mortality and complication rates ${ }^{1,2}$. Nextgeneration valves have been designed to improve annular sealing and reduce paravalvular regurgitation, but it appears that this comes at the price of an increased rate of new conduction disorders ${ }^{3,4}$. In particular, the occurrence of a new left bundle branch block and the need for a permanent pacemaker remain a matter of concern ${ }^{5,6}$.

The self-expandingACURATEneo ${ }^{\text {TM }}$ TF system(Boston Scientific, Marlborough, MA, USA) received CE-mark approval in 2014 and has design features aimed at preventing new conduction disorders. It has been associated with low pacemaker rates in the TF89 cohort and the recently presented SAVI TF 1,000-patient registry ${ }^{7}$.

Aside from device development, optimising the procedure and establishing best practices may further reduce complication rates ${ }^{8}$. In a recent study using the CoreValve ${ }^{\circledR}$ prosthesis (Medtronic, Minneapolis, MN, USA), predilatation with a smaller valvuloplasty balloon resulted in significantly lower pacemaker implantation rates 9

In our series, we aimed to assess whether the rate of conduction disorders and pacemaker implantations after ACURATE neo implantation can be further reduced by careful selection of the balloon size of predilatation and post-dilatation balloons, hence minimising the trauma to the aortic annulus and left ventricular outflow tract.

\section{Editorial, see page 1255}

\section{Methods}

\section{STUDY POPULATION}

All patients undergoing TAVI for the treatment of severe aortic stenosis with the self-expanding ACURATE neo transcatheter heart valve at three centres in Europe, the Heart Center Lucerne (Switzerland, $\mathrm{n}=78$ ), the Karolinska University Hospital (Stockholm, Sweden, $\mathrm{n}=66$ ), and the Odense University Hospital (Odense, Denmark, $\mathrm{n}=31$ ), were analysed. Data were collected throughout the initial hospital stay and follow-up was conducted at 30 days post procedure. The study complies with the Declaration of Helsinki. Prospective data acquisition after TAVI was approved by all ethics committees. All patients provided written informed consent for the TAVI procedure and for prospective data acquisition and follow-up examinations.

\section{TAVI WORK-UP, PROCEDURE, AND POST-PROCEDURAL MONITORING}

Potential TAVI candidates were discussed by the interdisciplinary Heart Team consisting of non-invasive cardiologists, interventional cardiologists, and cardiac surgeons. The valve size was chosen according to the perimeter of the annulus (a small "S" valve for annular perimeters $<72 \mathrm{~mm}$, a medium "M" valve for annular perimeters between 72 and $78 \mathrm{~mm}$, and a large "L" valve if the perimeter was between 79 and $84 \mathrm{~mm}$ ). In borderline cases, the larger valve was preferred. Due to the relatively low radial force of the inflow portion of the ACURATE neo THV, predilatation with a valvuloplasty balloon was performed in all patients (Figure 1). To minimise trauma to the annulus and the underlying conduction system, the diameter of the balloon was chosen 1-3 mm smaller than the perimeter-derived annular diameter. Post-dilatation was only performed in case of relevant aortic regurgitation or relevant antegrade flow gradient $(>10 \mathrm{mmHg})$ with a balloon 1-2 $\mathrm{mm}$ smaller than the perimeterderived annular diameter. Following TAVI, patients were monitored for one to three days, depending on the presence of a bundle branch block (BBB) or an atrioventricular block (AVB). In addition, an ECG was performed prior to discharge. The decision to implant a permanent pacemaker was left to the discretion of the operator.

\section{DEFINITIONS}

Clinical endpoints were defined according to the updated definitions of the Valve Academic Research Consortium (VARC) ${ }^{10}$. Conduction disorders included bundle branch blocks and atrioventricular blocks. A first-degree AVB was defined as a PQ time $\geq 200$ milliseconds (ms). A complete BBB was defined as a QRS duration $\geq 120 \mathrm{~ms}$ and the typical pattern of either left bundle branch block (LBBB) or right bundle branch block (RBBB). QRS duration $<120 \mathrm{~ms}$ was classified as no BBB. Implantation depth was measured on post-procedural supravalvular angiography as the distance between the lowest part of the THV frame and the ventricular tip of the non-coronary cusp. Valve oversizing was calculated as the difference between the nominal diameter of the THV (23, 25, and $27 \mathrm{~mm}$ for the S, M, and L THV, respectively) and the perimeter-derived annular diameter. Balloon undersizing was calculated as the difference between the perimeter-derived annular diameter and the diameter of the valvuloplasty balloon.

\section{STATISTICAL ANALYSIS}

If not otherwise indicated, data are presented as mean \pm standard deviation for continuous variables and as number and frequency for categorical variables. Continuous parametric variables were compared using the Student's t-test. Categorical variables were compared using the chi-square test or Fisher's exact test as appropriate. A logistic regression analysis was performed to calculate the odds ratio (OR) and the $95 \%$ confidence interval (CI) of variables predicting new conduction disorders at a significance level of $\mathrm{p}<0.05$. Statistical analyses were conducted with Stata version 13 (StataCorp, College Station, TX, USA) and tested using twosided tests at a significance level of 0.05 .

\section{Results}

From June 2015 to May 2016, 175 patients (58\% female) with a mean age of $83 \pm 6$ years were enrolled. Fourteen patients $(8.0 \%)$ 


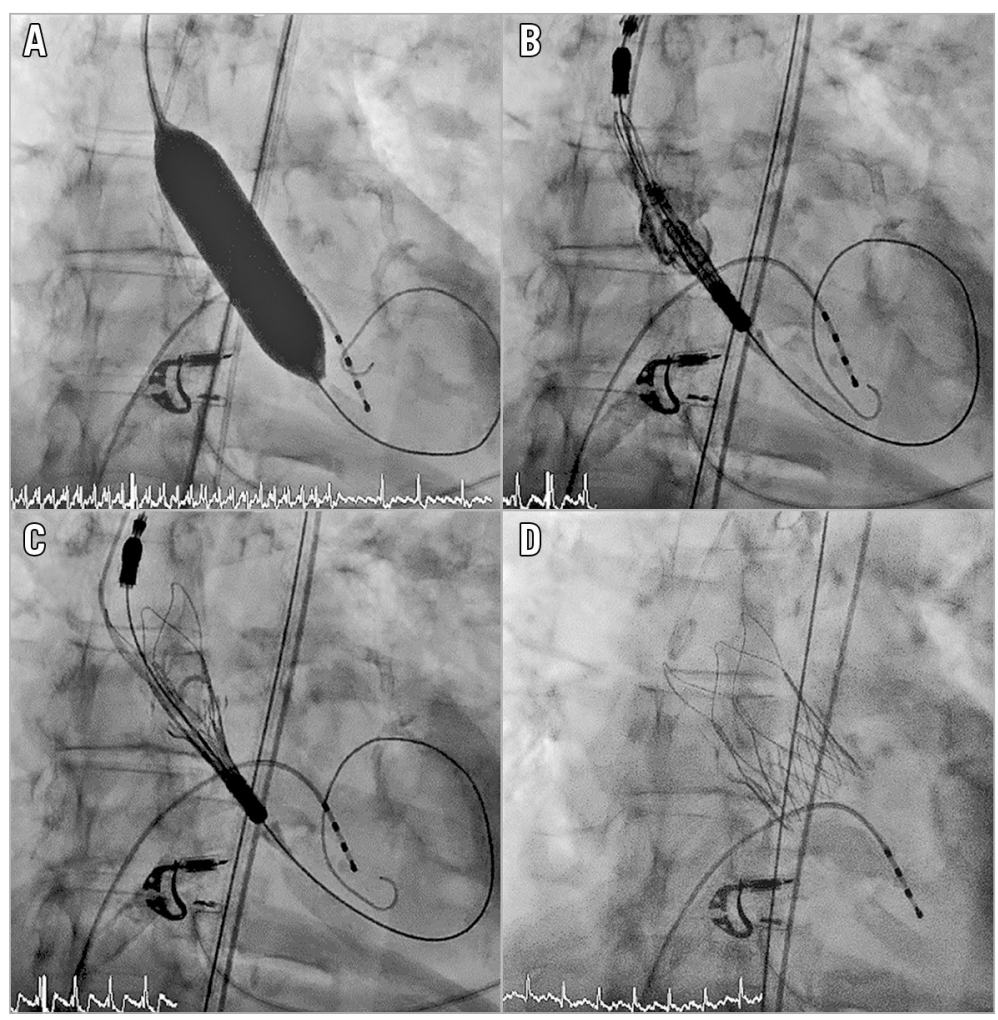

Figure 1. Implantation of the ACURATE neo transcatheter heart valve. Predilatation with a valvuloplasty balloon is generally recommended due to the relatively low radial force of the inflow part of the valve prosthesis (A). The valve is positioned $(B)$ and released top down $(C \& D)$.

had a permanent pacemaker at baseline. No "prophylactic" pacemaker implantations were performed before TAVI (e.g., pacemaker implantation in a patient with pre-existing RBBB and concomitant first-degree AV block). Baseline characteristics are summarised in Table 1.

\section{TAVI PROCEDURE AND OUTCOMES}

Procedural characteristics and outcomes are listed in Table 2. All patients underwent transfemoral TAVI with the ACURATE neo THV. Valve sizing was performed via ECG-gated computed tomography ( $n=166,95 \%)$; in patients with severe chronic kidney disease, magnetic resonance tomography (MRT) without the administration of gadolinium was carried out instead $(n=9,5 \%)$. The procedure was performed under local anaesthesia with mild conscious sedation in all patients. Predilatation was performed in all with a balloon diameter $1.9 \pm 0.9 \mathrm{~mm}$ smaller than the perimeter-derived annular diameter. Post-dilatation was performed in 46 patients $(26.3 \%)$ with a balloon diameter $1.1 \pm 0.9 \mathrm{~mm}$ smaller than the perimeter-derived annular diameter. TAVI reduced the mean transaortic gradient from $47 \pm 15 \mathrm{mmHg}$ to $7 \pm 4 \mathrm{mmHg}$ $(\mathrm{p}<0.01)$ and increased the aortic valve area from $0.7 \pm 0.2 \mathrm{~cm}^{2}$ to $2.0 \pm 0.4 \mathrm{~cm}^{2} \quad(\mathrm{p}<0.01)$. Paravalvular regurgitation (PAR) was none/trace in $66(37.7 \%)$, mild in 101 (57.7\%) and moderate in $8(4.6 \%)$. Patients were discharged after a median of three days post procedure (range 1-38 days). The 30-day stroke rate was $1.7 \%(3 / 175)$, and one patient $(0.6 \%)$ died (Table 3$)$.
Table 1. Baseline characteristics.

\begin{tabular}{|c|c|c|c|c|}
\hline & $\begin{array}{l}\text { All } \\
\text { patients } \\
(n=175)\end{array}$ & $\begin{array}{l}\text { Patients } \\
\text { without new } \\
\text { conduction } \\
\text { disorders } \\
(n=124)^{*}\end{array}$ & $\begin{array}{l}\text { Patients with } \\
\text { new } \\
\text { conduction } \\
\text { disorders } \\
(n=37)^{*}\end{array}$ & $p$-value \\
\hline Age, years & $83 \pm 6$ & $83 \pm 6$ & $83 \pm 4$ & 0.73 \\
\hline Female sex & $102(58 \%)$ & 79 (64\%) & $18(49 \%)$ & 0.10 \\
\hline Hypertension & $142(81 \%)$ & $100(81 \%)$ & 30 (81\%) & 0.95 \\
\hline Diabetes & $35(20 \%)$ & $20(16 \%)$ & $13(35 \%)$ & 0.01 \\
\hline $\begin{array}{l}\text { Coronary artery } \\
\text { disease }\end{array}$ & $59(34 \%)$ & $35(28 \%)$ & $15(41 \%)$ & 0.16 \\
\hline Prior stroke & $22(13 \%)$ & $13(10 \%)$ & $8(22 \%)$ & 0.08 \\
\hline $\begin{array}{l}\text { Beta-blocker at } \\
\text { admission }\end{array}$ & $91(52 \%)$ & $57(46 \%)$ & $24(65 \%)$ & 0.04 \\
\hline Prior pacemaker & $14(8 \%)$ & $N / A^{*}$ & $N / A^{*}$ & $N / A^{*}$ \\
\hline $\begin{array}{l}\text { Left bundle branch } \\
\text { block }\end{array}$ & $13(7 \%)$ & $11(8 \%)$ & $0(0 \%)$ & 0.07 \\
\hline $\begin{array}{l}\text { Right bundle branch } \\
\text { block }\end{array}$ & $15(9 \%)$ & $11(9 \%)$ & $3(8 \%)$ & 1.00 \\
\hline Atrial fibrillation & $33(19 \%)$ & $25(20 \%)$ & $4(11 \%)$ & 0.19 \\
\hline STS PROM, \% & $4.1 \pm 2.4$ & $3.8 \pm 2.1$ & $5.0 \pm 3.1$ & 0.049 \\
\hline Aortic valve area, $\mathrm{cm}^{2}$ & $0.70 \pm 0.16$ & $0.69 \pm 0.15$ & $0.75 \pm 0.18$ & 0.07 \\
\hline Mean gradient, $\mathrm{mmHg}$ & $48 \pm 15$ & $49 \pm 15$ & $43 \pm 14$ & 0.04 \\
\hline Ejection fraction, \% & $55 \pm 12$ & $56 \pm 11$ & $51 \pm 13$ & 0.05 \\
\hline \multicolumn{5}{|c|}{$\begin{array}{l}\text { Data are displayed as } n(\%) \text { or mean } \pm \text { SD. *Patients with a prior pacemaker were } \\
\text { excluded from subgroup analysis. STS PROM: Society of Thoracic Surgeons predicted } \\
\text { risk of mortality }\end{array}$} \\
\hline
\end{tabular}


Table 2. Procedural characteristics and post-procedural outcomes.

\begin{tabular}{|c|c|c|c|c|c|}
\hline & $\begin{array}{c}\text { All } \\
\text { patients } \\
(n=175)\end{array}$ & $\begin{array}{l}\text { Patients } \\
\text { without } \\
\text { new } \\
\text { conduction } \\
\text { disorders } \\
(\mathrm{n}=124)^{*}\end{array}$ & $\begin{array}{l}\text { Patients } \\
\text { with new } \\
\text { conduction } \\
\text { disorders } \\
(\mathrm{n}=37)^{*}\end{array}$ & $p$-value \\
\hline \multicolumn{2}{|c|}{$\begin{array}{l}\text { Perimeter-derived annular } \\
\text { diameter, } \mathrm{mm}\end{array}$} & $24.0 \pm 1.5$ & $23.9 \pm 1.5$ & $24.4 \pm 1.2$ & 0.11 \\
\hline \multicolumn{2}{|c|}{$\begin{array}{l}\text { Area-derived annular } \\
\text { diameter, } \mathrm{mm}\end{array}$} & $23.5 \pm 1.4$ & $23.4 \pm 1.5$ & $23.9 \pm 1.1$ & 0.16 \\
\hline \multicolumn{2}{|c|}{$\begin{array}{l}\text { Mean annular diameter, } \\
\mathrm{mm}\end{array}$} & $23.6 \pm 1.5$ & $23.5 \pm 1.6$ & $24.0 \pm 1.1$ & 0.20 \\
\hline \multirow{3}{*}{$\begin{array}{l}\text { Implanted } \\
\text { valve size }\end{array}$} & S & $31(18 \%)$ & $25(20 \%)$ & $4(11 \%)$ & \multirow{3}{*}{0.25} \\
\hline & M & 75 (43\%) & $55(44 \%)$ & $15(41 \%)$ & \\
\hline & L & $69(39 \%)$ & $44(36 \%)$ & $18(47 \%)$ & \\
\hline \multicolumn{2}{|c|}{ Valve oversizing, mm } & $1.4 \pm 0.8$ & $1.4 \pm 0.8$ & $1.4 \pm 0.8$ & 0.99 \\
\hline \multicolumn{2}{|c|}{$\begin{array}{l}\text { Predilatation balloon size, } \\
\text { mm }\end{array}$} & $22.2 \pm 1.6$ & $22.1 \pm 1.6$ & $22.5 \pm 1.5$ & 0.15 \\
\hline \multicolumn{2}{|c|}{$\begin{array}{l}\text { Predilatation balloon } \\
\text { undersizing, } \mathrm{mm}\end{array}$} & $1.9 \pm 0.9$ & $1.8 \pm 0.8$ & $1.9 \pm 1.1$ & 0.84 \\
\hline \multicolumn{2}{|c|}{ Need for post-dilatation } & $46(26 \%)$ & $37(30 \%)$ & $6(16 \%)$ & 0.10 \\
\hline \multicolumn{2}{|c|}{$\begin{array}{l}\text { Post-dilatation balloon } \\
\text { size, mm }\end{array}$} & $23.5 \pm 1.5$ & $22.9 \pm 2.4$ & $24.0 \pm 1.1$ & 0.08 \\
\hline \multicolumn{2}{|c|}{$\begin{array}{l}\text { Post-dilatation balloon } \\
\text { undersizing, mm }\end{array}$} & $1.1 \pm 0.9$ & $1.1 \pm 0.8$ & $1.1 \pm 1.5$ & 0.99 \\
\hline \multicolumn{2}{|c|}{ Implantation depth, mm } & $4.2 \pm 1.6$ & $4.1 \pm 1.5$ & $4.5 \pm 1.5$ & 0.34 \\
\hline \multicolumn{2}{|c|}{ Aortic valve area, $\mathrm{cm}^{2}$} & $2.0 \pm 0.4$ & $2.0 \pm 0.4$ & $1.8 \pm 0.4$ & 0.06 \\
\hline \multicolumn{2}{|c|}{ Mean gradient, mmHg } & $6.9 \pm 3.7$ & $6.8 \pm 3.8$ & $6.9 \pm 3.4$ & 0.95 \\
\hline \multirow{3}{*}{$\begin{array}{l}\text { Para- } \\
\text { valvular } \\
\text { regurgita- } \\
\text { tion }\end{array}$} & none/trace & $66(38 \%)$ & $46(37 \%)$ & $12(32 \%)$ & \multirow{3}{*}{0.57} \\
\hline & mild & $101(58 \%)$ & $73(59 \%)$ & 22 (59\%) & \\
\hline & moderate & $8(5 \%)$ & $5(4 \%)$ & $3(8 \%)$ & \\
\hline \multicolumn{2}{|c|}{$\begin{array}{l}\text { Major vascular } \\
\text { complication }\end{array}$} & $12(7 \%)$ & $7(6 \%)$ & $5(14 \%)$ & 0.27 \\
\hline \multicolumn{2}{|c|}{$\begin{array}{l}\text { Major or life-threatening } \\
\text { bleeding }\end{array}$} & $13(7 \%)$ & $7(6 \%)$ & $5(14 \%)$ & 0.26 \\
\hline \multicolumn{2}{|c|}{$\begin{array}{l}\text { Median duration of } \\
\text { hospitalisation, range }\end{array}$} & $3(1-38)$ & $3(1-38)$ & $4(2-28)$ & 0.95 \\
\hline \multicolumn{2}{|c|}{ Any stroke at 30 days } & $3(2 \%)$ & $3(2 \%)$ & $0(0 \%)$ & 0.34 \\
\hline \multicolumn{2}{|c|}{ Mortality at 30 days } & $1(1 \%)$ & $0(0 \%)$ & $1(3 \%)$ & 0.07 \\
\hline
\end{tabular}

Table 3. ECGs in patients requiring a permanent pacemaker.

\begin{tabular}{|c|c|c|c|c|}
\hline Patient & $\begin{array}{l}\text { ECG at } \\
\text { baseline }\end{array}$ & ECG after 24 hrs & $\begin{array}{l}\text { Reason for } \\
\text { pacemaker }\end{array}$ & $\begin{array}{c}\text { Timing } \\
\text { pacemaker } \\
\text { implant }\end{array}$ \\
\hline 1 & RBBB & Third-degree AVB & Third-degree AVB & Procedure day \\
\hline 2 & Unremarkable & $\begin{array}{l}\text { Short episode of } \\
\text { high-degree AVB on } \\
\text { telemetry }\end{array}$ & Third-degree AVB & Day 4 \\
\hline 3 & $\begin{array}{l}\text { RBBB, atrial } \\
\text { fibrillation }\end{array}$ & Third-degree AVB & Third-degree AVB & Next day \\
\hline 4 & RBBB & $\begin{array}{l}\text { RBBB, first-degree } \\
\text { AVB }\end{array}$ & $\begin{array}{c}\text { Delayed } \\
\text { high-degree AVB } \\
\text { on day } 5\end{array}$ & Day 6 \\
\hline
\end{tabular}

This patient died from coronary obstruction after the first THV was implanted too high and implantation of a second THV was required (SAPIEN 3; Edwards Lifesciences, Irvine, CA, USA).

\section{NEED FOR A NEW PERMANENT PACEMAKER AND CONDUCTION DISORDERS}

At discharge, 18 (10.3\%) patients had a new LBBB, one (0.6\%) a new RBBB, and $11(6.3 \%)$ a new first-degree AVB (Figure 2). Implantation of a new permanent pacemaker was required in four patients $(2.3 \%$, excluding patients with a prior pacemaker: $2.5 \%)$. Of these, three $(75 \%)$ had a complete RBBB at baseline (OR 39.8, 95\% CI: 3.8-411.8, p<0.01). Significant predictors for new conduction disorders were the presence of diabetes (OR 2.8, 95\% CI: 1.2-6.4, p=0.01), beta-blocker at baseline (OR 2.2, 95\% CI: $1.0-4.6, \mathrm{p}=0.046)$, and a lower mean transaortic gradient at baseline (OR 0.97, 95\% CI: 0.94-0.99, $\mathrm{p}=0.046$ ).

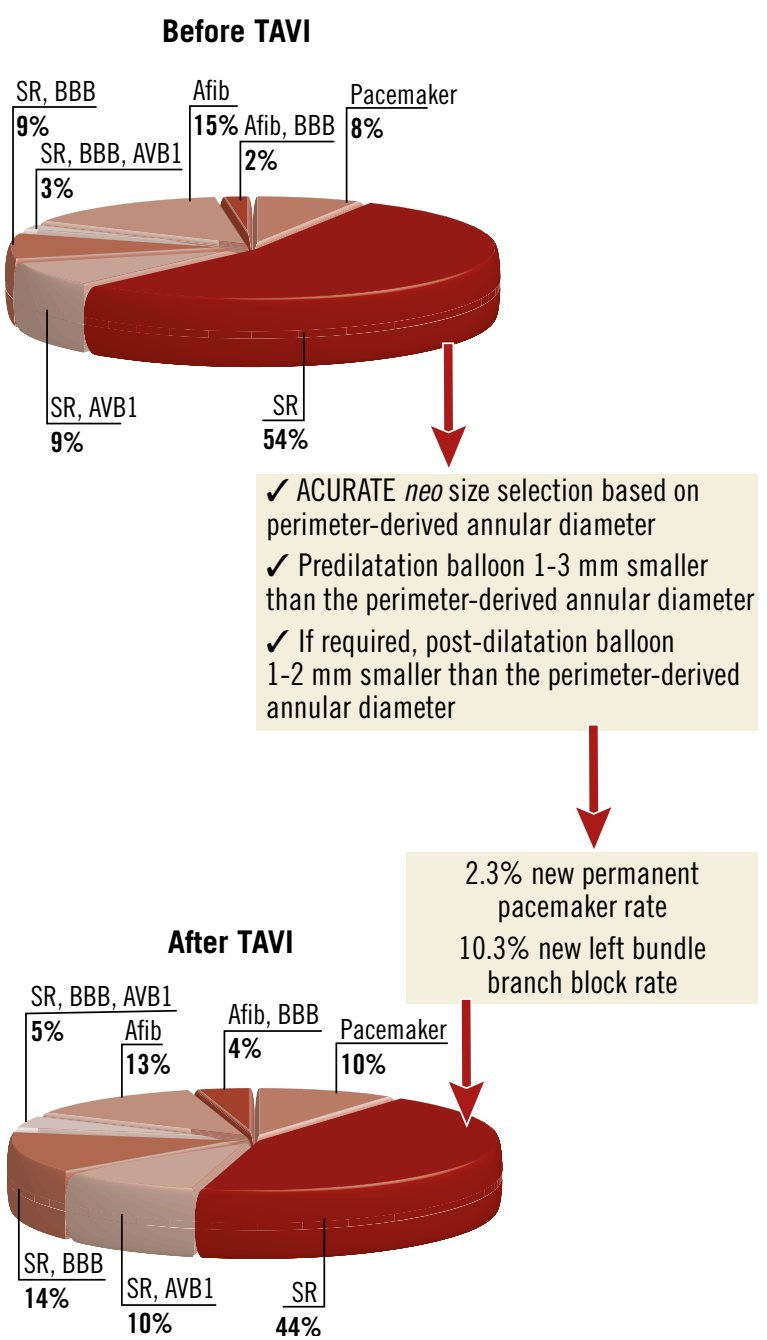

Figure 2. ECG findings at baseline and before discharge. With careful selection of the valvuloplasty balloon and the transcatheter heart valve size, a new left bundle branch block occurred in $17(10.0 \%)$ patients, and only four $(2.3 \%)$ required implantation of a new permanent pacemaker. 


\section{Discussion}

To the best of our knowledge, this study reports the lowest pacemaker rate that has ever been published after TAVI in a large series of patients. As TAVI relies on oversizing to anchor the device within the native annulus and thus applies force to adjacent structures such as the conduction system, many experts believe that pacemaker rates after TAVI will always be higher than after open heart surgery. In particular, self-expanding valves have been associated with high pacemaker rates, ranging between 10 and $35 \%{ }^{11-14}$. Our study, however, shows that, with careful selection of the balloon and prosthesis size, it is possible to achieve a very low pacemaker rate that compares well to surgical aortic valve implantation with new permanent pacemaker ranging between 3.6 and $7.1 \%$ in recent trials ${ }^{15-17}$. The pacemaker rate was only $2.3 \%$ including patients with a prior pacemaker and $2.5 \%$ after excluding such patients. Similarly, the rate of new LBBB was only $10 \%$. Furthermore, 30-day mortality was very low with only one patient who died $(0.6 \%)$. Notably, these outcomes did not come at the price of increased moderate PAR which was still below $5 \%$. However, the rate of mild PAR was relatively high in this study (58\%), and only $38 \%$ of patients had none/trace PAR. The next generation of the ACURATE neo, the ACURATE neo AS, is currently being studied in a CE-mark trial. This THV will feature a modified skirt aimed at reducing the rate of PAR. Whether this modification will result in higher rates of new LBBB or new permanent pacemakers is not yet known.

\section{PATHOPHYSIOLOGY OF NEW CONDUCTION DISORDERS}

New conduction disorders after TAVI represent frequent complications, particularly after implantation of self-expanding $\mathrm{THVs}^{2,17}$. Such valves apply a continuous radial force to the annular tissue and, in case of a deeper implantation, also to the left ventricular outflow tract. The target implantation depth of the ACURATE neo valve is about $4 \mathrm{~mm}$ below the annular level. The very low rate of LBBB and the need for a permanent pacemaker observed in the present study might appear surprising at first. However, the radial force of the ACURATE neo THV is relatively low, especially at the inflow portion of the frame, which may be in the immediate vicinity of the AV conduction system (Figure 3). This distribution of radial force may explain our study results. Previous studies have identified several risk factors for implantation of a permanent pacemaker, including pre-existing conduction disorders such as RBBB, bradycardia and the presence of AV block, membranous septum height, cusp calcification, implantation of a self-expanding valve, implantation depth, and post-procedural conduction disorders ${ }^{18,19}$. However, there may be differences among different THVs. In fact, in our series, there was no difference in implantation depth or the degree of valve oversizing between patients who experienced a new conduction disorder and those who did not. Furthermore, the ACURATE neo THVs are available in $2 \mathrm{~mm}$ increments, which may allow more precise sizing.

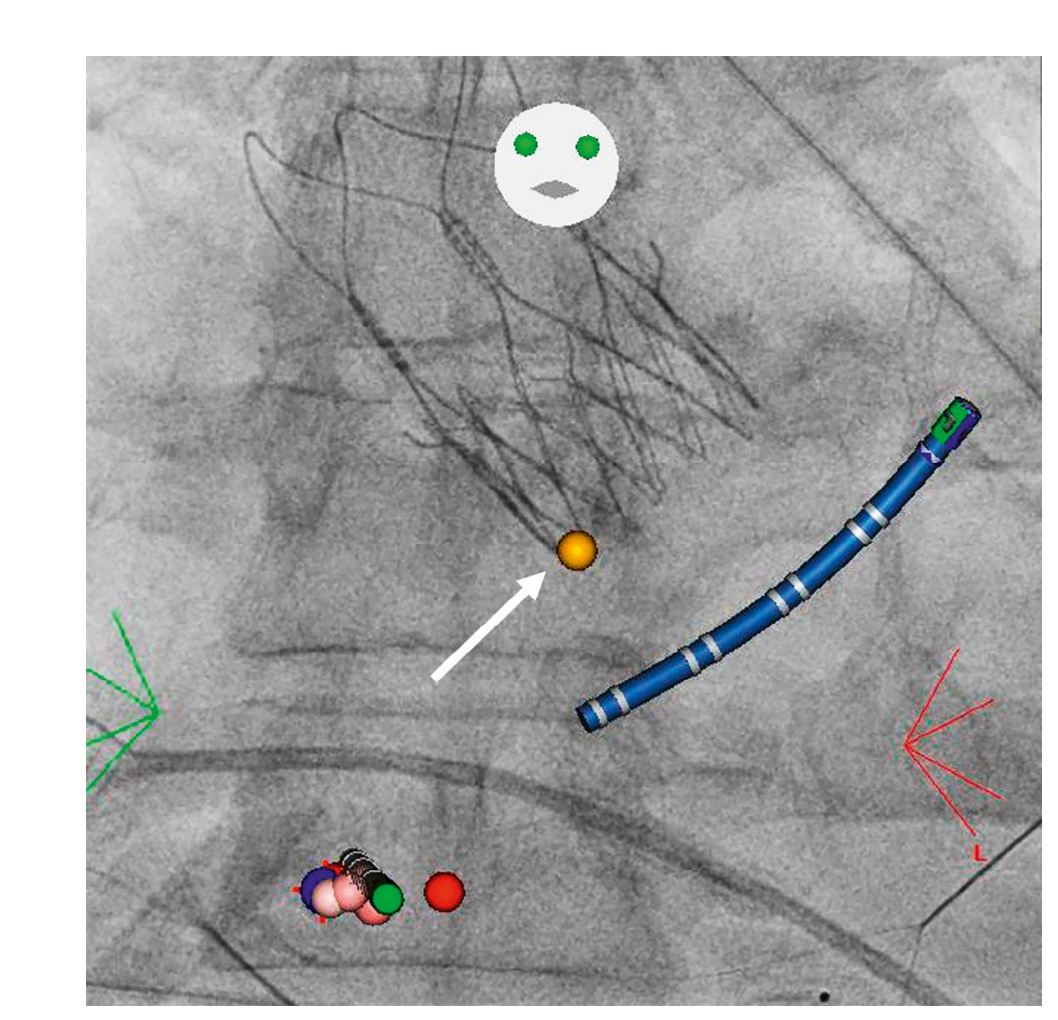

Figure 3. Prosthesis location in relation to the atrioventricular node. This image was taken in a patient who underwent radiofrequency ablation for atrial flutter three months after implantation of an ACURATE neo transcatheter heart valve using the CARTO 3 CARTOUNIVU TM System (Biosense Webster, Irvine, CA, USA). The yellow dot (arrow) shows the location of the atrioventricular node, in the immediate vicinity of the inflow portion of the valve frame. Red and pink points show the ablation line; the catheter is shown in blue. 
Van Gils et al compared the rate of permanent pacemaker implants in patients with baseline RBBB treated with different THVs. As baseline RBBB is a known predictor for pacemaker implants, rates were high at $75 \%$ for LOTUS ${ }^{\mathrm{TM}}$ (Boston Scientific), $46 \%$ for CoreValve, 32\% for SAPIEN XT (Edwards Lifesciences) and $34 \%$ for SAPIEN $3{ }^{20}$. With the caveat that only 15 patients with a baseline RBBB were present in our series, only $20 \%$ of patients with $\mathrm{RBBB}(3 / 15)$ received a pacemaker. Furthermore, three out of four patients with a pacemaker implant had an RBBB at baseline.

\section{RELEVANCE OF NEW CONDUCTION DISORDERS}

Available data on the clinical relevance of conduction disorders after TAVI remain controversial ${ }^{21}$. The presence of a new LBBB has been associated with an increased risk of cardiac death ${ }^{21,22}$ and a lack of improvement in ejection fraction ${ }^{23}$. The need for a new permanent pacemaker has been associated with reduced survival in some studies ${ }^{24}$, but not all ${ }^{21,25,26}$. A recent meta-analysis has even found a trend towards a protective effect from cardiac death in the first year after the procedure ${ }^{21}$. One possible explanation may be that patients with new-onset LBBB are at higher risk for cardiac death because of the potential progression towards complete AVB and sudden death, which possibly may have been prevented by implantation of a permanent pacemaker ${ }^{21,27}$. Furthermore, evidence indicates that a subset of these conduction disorders may resolve over time, and not all patients receiving a permanent pacemaker may actually be paced during follow-up ${ }^{28,29}$. Not surprisingly, new conduction disorders and implantation of a permanent pacemaker have been linked with prolonged hospital stay and $\operatorname{costs}^{30}$. New conduction disorders complicate in-hospital management, as patients with a new LBBB or a new first-degree AVB may progress towards complete AVB and therefore require telemetry monitoring. A recent publication suggested that such patients should be monitored until the ECG remains stable for at least 48 hours. On the other hand, the risk of delayed high-degree AVB was extremely low in the absence of relevant conduction disorders after TAVI. In the absence of other complications, patients without relevant conduction disorders after TAVI may be candidates for safe, early discharge ${ }^{31}$. In summary, a low rate of conduction disorders, particularly LBBB and first-degree AVB, and a low rate of new permanent pacemakers may facilitate in-hospital patient management, reduce the duration of in-hospital stay, and costs, and might improve long-term prognosis.

\section{Study limitations}

This is a retrospective analysis of prospectively acquired data and is therefore subject to the limitations of such a study design. The patient number is relatively small. No core laboratory analysis was performed, but ECGs and echocardiograms were analysed by experienced cardiologists. Further, calcification was not systematically assessed. Due to the low number of patients with new conduction disorders, no multivariable logistic regression analysis was performed.

\section{Conclusions}

With careful selection of the valvuloplasty balloon and the ACURATE neo prosthesis size, very low rates of new conduction disorders and permanent pacemaker implantation may be achieved without increasing the amount of paravalvular regurgitation. This may facilitate post-procedural patient management, reduce the duration of in-hospital stay, and costs, and may ultimately improve long-term prognosis.

\section{Impact on daily practice}

Predilatation, or (if applicable) post-dilatation, choosing a balloon size 1-2 mm smaller than the perimeter-derived annular diameter, was associated with very low conduction disorders and permanent pacemaker rates following transfemoral implantation of the ACURATE neo transcatheter heart valve. With this technique, it appears that the permanent pacemaker rate may be reduced below the level of surgical aortic valve implantation. This may lead to a paradigm shift such that TAVI does not essentially have to be associated with higher rates of permanent pacemakers.

\section{Conflict of interest statement}

S. Toggweiler serves as a proctor and consultant to Symetis/ Boston Scientific, is a consultant to NVT, and has received speaker fees from Symetis/Boston Scientific, Edwards Lifesciences and Medtronic. A. Rück serves as a proctor to Symetis/Boston Scientific and has received grants from Medtronic, St. Jude Medical and Symetis/Boston Scientific. The other authors have no conflicts of interest to declare.

\section{References}

1. Linke A, Wenaweser P, Gerckens U, Tamburino C, Bosmans J, Bleiziffer S, Blackman D, Schäfer U, Müller R, Sievert H, Søndergaard L, Klugmann S, Hoffmann R, Tchétché D, Colombo A, Legrand VM, Bedogni F, lePrince P, Schuler G, Mazzitelli D, Eftychiou C, Frerker C, Boekstegers P, Windecker S, Mohr FW, Woitek F, Lange R, Bauernschmitt R, Brecker S; ADVANCE study Investigators. Treatment of aortic stenosis with a self-expanding transcatheter valve: the International Multi-centre ADVANCE Study. Eur Heart J. 2014;35:2672-84.

2. Popma JJ, Adams DH, Reardon MJ, Yakubov SJ, Kleiman NS, Heimansohn D, Hermiller J Jr, Hughes GC, Harrison JK, Coselli J, Diez J, Kafi A, Schreiber T, Gleason TG, Conte J, Buchbinder M, Deeb GM, Carabello B, Serruys PW, Chenoweth S, Oh JK; CoreValve United States Clinical Investigators. Transcatheter aortic valve replacement using a self-expanding bioprosthesis in patients with severe aortic stenosis at extreme risk for surgery. J Am Coll Cardiol. 2014;63:1972-81.

3. Meredith IT, Worthley SG, Whitbourn RJ, Antonis P, Montarello JK, Newcomb AE, Lockwood S, Haratani N, Allocco DJ, Dawkins KD. Transfemoral aortic valve replacement with the repositionable Lotus Valve System in high surgical risk patients: the REPRISE I study. EuroIntervention. 2014;9:1264-70. 
4. Binder RK, Rodés-Cabau J, Wood DA, Mok M, Leipsic J, De Larochellière R, Toggweiler S, Dumont E, Freeman M, Willson AB, Webb JG. Transcatheter aortic valve replacement with the SAPIEN 3: a new balloon-expandable transcatheter heart valve. JACC Cardiovasc Interv. 2013;6:293-300.

5. Urena M, Rodés-Cabau J. Permanent pacemaker implantation following transcatheter aortic valve replacement: still a concern? JACC Cardiovasc Interv. 2015;8:70-3.

6. Bax JJ, Delgado V, Bapat V, Baumgartner H, Collet JP, Erbel R, Hamm C, Kappetein AP, Leipsic J, Leon MB, MacCarthy P, Piazza N, Pibarot P, Roberts WC, Rodés-Cabau J, Serruys PW, Thomas M, Vahanian A, Webb J, Zamorano JL, Windecker S. Open issues in transcatheter aortic valve implantation. Part 1: patient selection and treatment strategy for transcatheter aortic valve implantation. Eur Heart J. 2014;35:2627-38.

7. Schäfer U, Conradi L, Diemert P, Deuschl F, Schofer N, Seiffert M, Lubos E, Schirmer J, Reichenspurner H, Blankenberg S, Treede H. Symetis ACURATE TAVI: review of the technology, developments and current data with this self-expanding transcatheter heart valve. Minerva Cardioangiol. 2015;63:359-69.

8. Sinning JM, Petronio AS, Van Mieghem N, Zucchelli G, Nickenig G, Bekeredjian R, Bosmans J, Bedogni F, Branny M, Stangl K, Kovac J, Nordell A, Schiltgen M, Piazza N, de Jaegere P. Relation Between Clinical Best Practices and 6-Month Outcomes After Transcatheter Aortic Valve Implantation With CoreValve (from the ADVANCE II Study). Am J Cardiol. 2017;119:84-90.

9. Lange P, Greif M, Vogel A, Thaumann A, Helbig S, Schwarz F, Schmitz C, Becker C, D’Anastasi M, Boekstegers P, Pohl T, Laubender RP, Steinbeck G, Kupatt C. Reduction of pacemaker implantation rates after CoreValve ${ }^{\circledR}$ implantation by moderate predilatation. EuroIntervention. 2014;9:1151-7.

10. Kappetein AP, Head SJ, Généreux P, Piazza N, van Mieghem NM, Blackstone EH, Brott TG, Cohen DJ, Cutlip DE, van Es GA, Hahn RT, Kirtane AJ, Krucoff MW, Kodali S, Mack MJ, Mehran R, Rodés-Cabau J, Vranckx P, Webb JG, Windecker S, Serruys PW, Leon MB. Updated standardized endpoint definitions for transcatheter aortic valve implantation: the Valve Academic Research Consortium-2 consensus document. J Am Coll Cardiol. 2012;60:1438-54.

11. Siontis GC, Praz F, Pilgrim T, Mavridis D, Verma S, Salanti G, Søndergaard L, Jüni P, Windecker S. Transcatheter aortic valve implantation vs. surgical aortic valve replacement for treatment of severe aortic stenosis: a meta-analysis of randomized trials. Eur Heart J. 2016;37:3503-12.

12. Siontis GC, Jüni P, Pilgrim T, Stortecky S, Büllesfeld L, Meier B, Wenaweser P, Windecker S. Predictors of permanent pacemaker implantation in patients with severe aortic stenosis undergoing TAVR: a meta-analysis. J Am Coll Cardiol. 2014;64:129-40.

13. Manoharan G, Walton AS, Brecker SJ, Pasupati S, Blackman DJ, Qiao H, Meredith IT. Treatment of Symptomatic Severe Aortic Stenosis With a Novel Resheathable Supra-Annular Self-Expanding Transcatheter Aortic Valve System. JACC Cardiovasc Interv. 2015;8:1359-67.
14. Manoharan G, Linke A, Moellmann H, Redwood S, Frerker C, Kovac J, Walther T. Multicentre clinical study evaluating a novel resheathable annular functioning self-expanding transcatheter aortic valve system: safety and performance results at 30 days with the Portico system. EuroIntervention. 2016;12:768-74.

15. Leon MB, Smith CR, Mack MJ, Makkar RR, Svensson LG, Kodali SK, Thourani VH, Tuzcu EM, Miller DC, Herrmann HC, Doshi D, Cohen DJ, Pichard AD, Kapadia S, Dewey T, Babaliaros V, Szeto WY, Williams MR, Kereiakes D, Zajarias A, Greason KL, Whisenant BK, Hodson RW, Moses JW, Trento A, Brown DL, Fearon WF, Pibarot P, Hahn RT, Jaber WA, Anderson WN, Alu MC, Webb JG; PARTNER 2 Investigators. Transcatheter or Surgical Aortic-Valve Replacement in Intermediate-Risk Patients. $N$ Engl J Med. 2016;374:1609-20.

16. Smith CR, Leon MB, Mack MJ, Miller DC, Moses JW, Svensson LG, Tuzcu EM, Webb JG, Fontana GP, Makkar RR, Williams M, Dewey T, Kapadia S, Babaliaros V, Thourani VH, Corso P, Pichard AD, Bavaria JE, Herrmann HC, Akin JJ, Anderson WN, Wang D, Pocock SJ; PARTNER Trial Investigators. Transcatheter versus surgical aortic-valve replacement in high-risk patients. N Engl J Med. 2011;364:2187-98.

17. Adams DH, Popma JJ, Reardon MJ, Yakubov SJ, Coselli JS, Deeb GM, Gleason TG, Buchbinder M, Hermiller J Jr, Kleiman NS, Chetcuti S, Heiser J, Merhi W, Zorn G, Tadros P, Robinson N, Petrossian G, Hughes GC, Harrison JK, Conte J, Maini B, Mumtaz M, Chenoweth S, Oh JK; U.S. CoreValve Clinical Investigators. Transcatheter aortic-valve replacement with a selfexpanding prosthesis. N Engl J Med. 2014;370:1790-8.

18. Maeno Y, Abramowitz Y, Kawamori H, Kazuno Y, Kubo S, Takahashi N, Mangat G, Okuyama K, Kashif M, Chakravarty T, Nakamura M, Cheng W, Friedman J, Berman D, Makkar RR, Jilaihawi H. A Highly Predictive Risk Model for Pacemaker Implantation After TAVR. JACC Cardiovasc Imaging. 2017;10(10 Pt A):1139-1147.

19. Kapadia SR, Wazni O, Krishnaswamy A. Pacemaker Implantation After TAVR. JACC Cardiovasc Imaging. 2017; 10:1148-50.

20. van Gils L, Tchetche D, Lhermusier T, Abawi M, Dumonteil N, Rodriguez Olivares R, Molina-Martin de Nicolas J, Stella PR, Carrié D, De Jaegere PP, Van Mieghem NM. Transcatheter Heart Valve Selection and Permanent Pacemaker Implantation in Patients With Pre-Existent Right Bundle Branch Block. J Am Heart Assoc. 2017 Mar 3;6(3).

21. Regueiro A, Abdul-Jawad Altisent O, Del Trigo M, CampeloParada F, Puri R, Urena M, Philippon F, Rodés-Cabau J. Impact of New-Onset Left Bundle Branch Block and Periprocedural Permanent Pacemaker Implantation on Clinical Outcomes in Patients Undergoing Transcatheter Aortic Valve Replacement: A Systematic Review and Meta-Analysis. Circ Cardiovasc Interv. 2016;9:e003635.

22. Urena M, Webb JG, Eltchaninoff H, Muñoz-García AJ, Bouleti C, Tamburino C, Nombela-Franco L, Nietlispach F, Moris C, Ruel M, Dager AE, Serra V, Cheema AN, Amat-Santos IJ, de Brito FS, Lemos PA, Abizaid A, Sarmento-Leite R, Ribeiro HB, 
Dumont E, Barbanti M, Durand E, Alonso Briales JH, Himbert D, Vahanian A, Immè S, Garcia E, Maisano F, del Valle R, Benitez LM, García del Blanco B, Gutiérrez H, Perin MA, Siqueira D, Bernardi G, Philippon F, Rodés-Cabau J. Late cardiac death in patients undergoing transcatheter aortic valve replacement: incidence and predictors of advanced heart failure and sudden cardiac death. J Am Coll Cardiol. 2015;65:437-48.

23. Urena M, Webb JG, Cheema A, Serra V, Toggweiler S, Barbanti M, Cheung A, Ye J, Dumont E, DeLarochellière R, Doyle D, Al Lawati HA, Peterson M, Chisholm R, Igual A, Ribeiro HB, Nombela-Franco L, Philippon F, Garcia Del Blanco B, Rodés-Cabau J. Impact of new-onset persistent left bundle branch block on late clinical outcomes in patients undergoing transcatheter aortic valve implantation with a balloon-expandable valve. JACC Cardiovasc Interv. 2014;7:128-36.

24. Nazif TM, Dizon JM, Hahn RT, Xu K, Babaliaros V, Douglas PS, El-Chami MF, Herrmann HC, Mack M, Makkar RR, Miller DC, Pichard A, Tuzcu EM, Szeto WY, Webb JG, Moses JW, Smith CR, Williams MR, Leon MB, Kodali SK; PARTNER Publications Office. Predictors and clinical outcomes of permanent pacemaker implantation after transcatheter aortic valve replacement: the PARTNER (Placement of AoRtic TraNscathetER Valves) trial and registry. JACC Cardiovasc Interv. 2015;8:60-9.

25. Buellesfeld L, Stortecky S, Heg D, Hausen S, Mueller R, Wenaweser P, Pilgrim T, Gloekler S, Khattab AA, Huber C, Carrel T, Eberle B, Meier B, Boekstegers P, Jüni P, Gerckens U, Grube E, Windecker S. Impact of permanent pacemaker implantation on clinical outcome among patients undergoing transcatheter aortic valve implantation. J Am Coll Cardiol. 2012;60:493-501.

26. Engborg J, Riechel-Sarup C, Gerke O, Mickley H, Sandgaard NC, Nissen H, Diederichsen AC. Effect of permanent pacemaker on mortality after transcatheter aortic valve replacement. Scand Cardiovasc J. 2017;51:40-6.

27. Zhang ZM, Rautaharju PM, Soliman EZ, Manson JE, Cain ME, Martin LW, Bavry AA, Mehta L, Vitolins M, Prineas RJ. Mortality risk associated with bundle branch blocks and related repolarization abnormalities (from the Women's Health Initiative [WHI]). Am J Cardiol. 2012;110:1489-95.

28. van der Boon RM, Van Mieghem NM, Theuns DA, Nuis RJ, Nauta ST, Serruys PW, Jordaens L, van Domburg RT, de Jaegere PP. Pacemaker dependency after transcatheter aortic valve implantation with the self-expanding Medtronic CoreValve System. Int $J$ Cardiol. 2013;168:1269-73.

29. Boerlage-Van Dijk K, Kooiman KM, Yong ZY, Wiegerinck EM, Damman P, Bouma BJ, Tijssen JG, Piek JJ, Knops RE, Baan J Jr. Predictors and permanency of cardiac conduction disorders and necessity of pacing after transcatheter aortic valve implantation. Pacing Clin Electrophysiol. 2014;37:1520-9.

30. Arnold SV, Lei Y, Reynolds MR, Magnuson EA, Suri RM, Tuzcu EM, Petersen JL 2nd, Douglas PS, Svensson LG, Gada H, Thourani VH, Kodali SK, Mack MJ, Leon MB, Cohen DJ; PARTNER Investigators. Costs of periprocedural complications in patients treated with transcatheter aortic valve replacement: results from the Placement of Aortic Transcatheter Valve trial. Circ Cardiovasc Interv. 2014;7:829-36.

31. Toggweiler S, Stortecky S, Holy E, Zuk K, Cuculi F, Nietlispach F, Sabti Z, Suciu R, Maier W, Jamshidi P, Maisano F, Windecker S, Kobza R, Wenaweser P, Lüscher TF, Binder RK. The Electrocardiogram After Transcatheter Aortic Valve Replacement Determines the Risk for Post-Procedural High-Degree AV Block and the Need for Telemetry Monitoring. JACC Cardiovasc Interv. 2016;9:1269-76. 